\title{
Synthesis and catalytic study in the Suzuki-Miyaura reaction of a family of palladium compounds ${ }^{+}$
}

\author{
Fátima Lucio-Martínez*, Paula Polo, Paula Munín, Francisco Reigosa, Adolfo Fernández, Teresa \\ Pereira and José M. Vila* \\ Departamento de Química Inorgánica, Universidad de Santiago de Compostela, Avenida de las Ciencias s/n \\ 15782, Santiago de Compostela, Spain. \\ *mariadefatima.lucio@usc.es; Tel.: +34-881-814-442 \\ * josemanuel.vila@usc.es \\ + The 21 $1^{\text {st }}$ International Electronic Conference on Synthetic Organic Chemistry. 1-30 November 2017
}

Academic Editor: Dr. Julio A. Seijas Vázquez

Received: date; Accepted: date; Published: date

\begin{abstract}
Thiosemicarbazone ligands are known for their versatility towards metal coordination, forming very stable compounds with metals such as palladium. In addition, palladium derivatives are used more often than not as catalyst in $\mathrm{C}-\mathrm{C}$ cross coupling reactions like the Suzuki-Miyaura reaction, however the commercially available catalyst are not of much air or thermal stability. That is the reason why in this communication we present the synthesis, characterisation and catalytic study of a family of palladium - thiosemicarbazone compounds as an improvement to the thermal and air stability of commercial catalyst.
\end{abstract}

Keywords: Palladium, catalysis, Suzuki-Miyaura

\section{Introduction}

Carbon-Carbon cross-coupling reactions are of great relevance in organic synthesis [1] and also, in industrial and in pharmaceutical processes. Palladium based compounds appear to be outstanding catalysts in the $\mathrm{C}-\mathrm{C}$ cross-coupling reactions [2], and although there are commercially available catalysts such as $\left[\mathrm{Pd}\left(\mathrm{PPh}_{3}\right)_{4}\right]$ or $\left[\mathrm{Pd}(\mathrm{OAc})_{2}\right]$, they fail to comply with air and thermal stability, so by tuning the ligands this problem can be overcome. Thiosemicarbazones are a family of ligands formed by the reaction between a carbonyl group and a tiosemicarbazide. They present different coordination modes from mono to tetradentate due to the presence of a variety of donor atoms in their structure, and in solution they present thiol-thione equilibrium [3]; although their most common coordinative fashion is as bidentate ligands forming a five membered ring, which is also the most stable [4]. Furthermore, thiosemicarbazone ligands themselves are known for showing cytotoxic activity. For this reason the combination of both functions makes palladium thiosemicarbazone compounds an interesting new tool in chemistry.

Given our vast experience in the synthesis and characterisation of cyclopalladated compounds [5] and their use as catalysts in the Suzuki-Miyaura reaction [6, 7], we reasoned that by using the thiosemicarbazone as bidentate instead of tridentate, the greater accessibility of palladium would give a better catalytic activity. For this reason the synthesis of ligands 1-3 (scheme1) was carried out. A thiophene substituent and substitution of the iminic methyl for hydrogen made formation of the cyclopalladated ring more difficult. What follows is the methodology and the results obtained. 


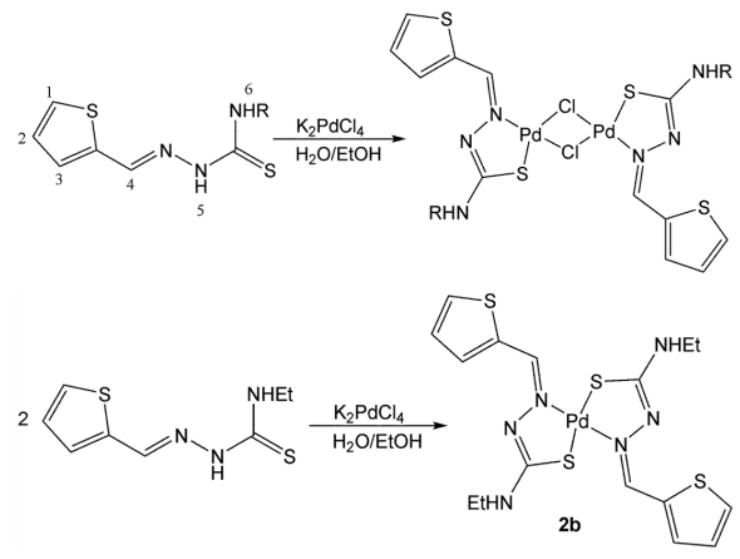

Scheme 1: Synthesis of the palladium derivatives.

\section{Discussion}

The compounds synthetized have been fully characterised using the standard spectroscopy techniques ${ }^{1} \mathrm{H}$ NMR, IR and X-ray diffraction in the case of compound $\mathbf{2} \mathbf{b}$. In all cases the displacement of the ${ }^{1} \mathrm{H}$ NMR signals to higher field proves that the thiosemicarbazone ligands (compounds 1-3) are attached to the metal giving compounds 1a-3a (see scheme 1).

The presence of the $\mathrm{H} 3$ resonance in the metalated compounds shows that the ligands act as bidentate $[\mathrm{N}, \mathrm{S}]$. In addition, absence of the signal for the hidrazinic proton indicates a thiolic coordination. This is corroborated in the case of the IR spectra due to the disappearance of the $v(C=S)$ stretch placed $\mathrm{ca} 805-860 \mathrm{~cm}^{-1}$ [8]. Finally, the synthesis of compound $\mathbf{2 b}$ provided crystals suitable for X-ray diffraction. The structure confirms without any doubt the thiol fashion of the thiosemicarbazone and the bidentate coordination in the solid state. This structure also shows the trans-disposition of both thiosemicarbazone ligands around the metal and the monomeric nature of the compound $\mathbf{2} \mathbf{b}$ as shown in figure 1.

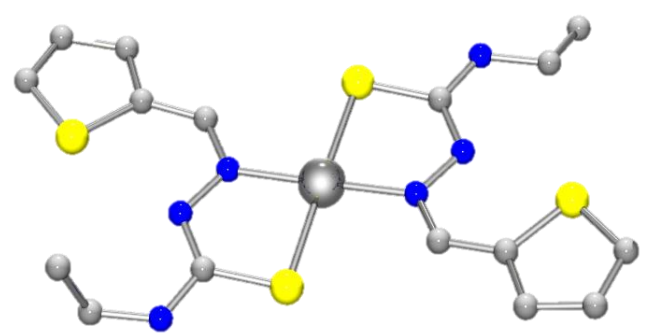

Figure 1: Molecular structure of compound 2b, the hydrogen atoms have been omitted for clarity.

Once the compounds were fully characterized they were tested as catalysts for the Suzuki-Miyaura reaction, using as substrates either 4'-bromoacetophene (as activating substrate) or 4'-bromoanisole (as deactivating substrate) together with phenylboronic acid (as described in the Materials and Methods section). The results are collected in the Table 1. From them it can be seen that the best conditions in the Suzuki-Miyaura reaction were $80^{\circ} \mathrm{C}$ using the activating substrate and using less favourable conditions the best catalyst was compound 2a. This result is opposed to the low catalytic activity of $\mathbf{2} \mathbf{b}$, so the presence of more labile bonds such as $\mathrm{Pd}-\mathrm{Cl}$ favours the catalytic activity of the compound. According to the data, the secondmost important factor is changing the NHR group. The greatest difference is between the NHMe and NHEt species (1a and 2a respectively). Changing one carbon in the chain the catalytic activity considerably. The major differences in the catalytic activity are in the entrance related to $40^{\circ} \mathrm{C}$ were $2 \mathrm{a}$ is still a good catalyst, however 1a and 3a cannot reach $50 \%$ conversion. 
Table 1: Results for the catalytic studies.

\begin{tabular}{|c|c|c|c|c|}
\hline Catalyst & $\mathrm{T} \circ \mathrm{C}$ & XAr & time/h & Max. Conv. \% \\
\hline \multirow[t]{4}{*}{ 1a } & 80 & 4'-bromoacetophenone & 24 & 37 \\
\hline & 40 & 4'-bromoacetophenone & 24 & 27 \\
\hline & r. t. & 4'-bromoacetophenone & 24 & 11 \\
\hline & 80 & 4'-bromoanisole & 24 & 6 \\
\hline \multirow[t]{4}{*}{$2 a$} & 80 & 4'-bromoacetophenone & 24 & 93 \\
\hline & 40 & $4^{\prime}$-bromoacetophenone & 24 & 79 \\
\hline & r.t. & 4'-bromoacetophenone & 24 & 27 \\
\hline & 80 & 4'-bromoanisole & 24 & 12 \\
\hline \multirow[t]{4}{*}{$2 b$} & 80 & 4'-bromoacetophenone & 24 & 14 \\
\hline & 40 & 4'-bromoacetophenone & 24 & 10 \\
\hline & r. t. & $4^{\prime}$-bromoacetophenone & 24 & 0 \\
\hline & 80 & 4'-bromoanisole & 24 & 0 \\
\hline \multirow[t]{4}{*}{$3 \mathbf{a}$} & 80 & 4'-bromoacetophenone & 24 & 92 \\
\hline & 40 & 4'-bromoacetophenone & 24 & 17 \\
\hline & r. t. & $4^{\prime}$-bromoacetophenone & 24 & 6 \\
\hline & 80 & 4'-bromoanisole & 24 & 2 \\
\hline
\end{tabular}

\section{Materials and Methods}

3.1 General Procedures. Solvents were purified by standard methods. All compounds were purchased from Sigma-Aldrich. Elemental analyses were performed with a LECO analyzer, Model CHNS-932. IR espectra were recorded as Nujol mulls or polythene discs on Perking-Elmer 1330, Mattson Model Cygnus-100, and Bruker Model IFS-66V spectrophotometers. ${ }^{1} \mathrm{H}$ NMR spectra in solution were recorded in $\mathrm{CDCl}_{3}$ or DMSO- $\mathrm{d}_{6}$ at room temperature on Bruker DPX 250 spectrometer operating at $250.13 \mathrm{MHz}$ using $5 \mathrm{~mm}$ o.d. tubes; chemical shifts, in ppm, are reported downfield relative to TMS using the solvent signal (DMSO- $\mathrm{d}_{6}, \delta^{1} \mathrm{H}=2.46 \mathrm{ppm}$ ) as reference. Coupling constants are reported in $\mathrm{Hz}$. All chemical shifts are reported downfield from standards.

3.2 Synthesis of the Ligands: 2-Thiophenecarboxaldehyde was added to a solution of 4-R-thiosemicarbazone ( $\mathrm{R}=\mathrm{Me}$, Et or Ph for compounds 1, 2 and 3 respectively) in acidified water. The mixtures were stirred for $4 \mathrm{~h}$ and the resulting pale yellow precipitates were filtrated, washed with water and dried.

3.2.1 Compound 1: yield 91\%, ${ }^{1} \mathrm{H}$ RMN $\left(D M S O-d_{6}\right) \delta$ ppm $7.64\left(\mathrm{~d},{ }^{3} J(\mathrm{H} 1 \mathrm{H} 2)=5.03 \mathrm{~Hz}, 1 \mathrm{H}, \mathrm{H} 1\right), 7.10$ $\left(\mathrm{dd}, 3 \mathrm{3}(\mathrm{H} 2 \mathrm{H} 1)=5.01,{ }^{3} \mathrm{~J}(\mathrm{H} 2 \mathrm{H} 3) 2.65 \mathrm{~Hz}, 1 \mathrm{H}, \mathrm{H} 2\right), 7.41(\mathrm{~d}, 3 \mathrm{~J}(\mathrm{H} 3 \mathrm{H} 2)=2.65 \mathrm{~Hz}, 1 \mathrm{H}, \mathrm{H} 3), 8.22(\mathrm{~s}, 1 \mathrm{H}, \mathrm{H} 4)$, 11.47 (s, 1H, H5) 8.15 (t, $\left.{ }^{3} J(\mathrm{H} 6 \mathrm{H} 7)=4.53 \mathrm{~Hz}, 1 \mathrm{H}, \mathrm{H6}\right), 2.98\left(\mathrm{~d},{ }^{3}(\mathrm{H} 7 \mathrm{H6})=4.60 \mathrm{~Hz}, 3 \mathrm{H}, \mathrm{H7}\right) . \mathrm{IR} \mathrm{cm}^{-1} 3173$ ( $\tilde{\mathrm{v}} \mathrm{NH}), 1593(\tilde{\mathrm{v}} \mathrm{C}=\mathrm{N}), 822$ ( $\tilde{\mathrm{v}} \mathrm{C}=\mathrm{S})$. Anal. Found: $\mathrm{C}, 42.4 ; \mathrm{H}, 4.6 ; \mathrm{N}, 21.0 ; \mathrm{S}, 32.1 \%, \mathrm{C}_{7} \mathrm{H}_{9} \mathrm{~N}_{3} \mathrm{~S}_{2}$ requires $\mathrm{C}, 42.2 ; \mathrm{H}, 4.6 ; \mathrm{N}, 21.0 ; \mathrm{S}, 32.1 \%$.

3.2.2 Compound 2: yield 93\% ${ }^{1} \mathrm{H}$ NMR $\left(D M S O-d_{6}\right) \delta$ ppm $7.64\left(\mathrm{~d},{ }^{3} J(\mathrm{H} 1 \mathrm{H} 2)=5.13 \mathrm{~Hz}, 1 \mathrm{H}, \mathrm{H} 1\right)$, 7.14-7.07 (m, 1H, H2), $7.42\left(\mathrm{~d},{ }^{3} \mathrm{~J}(\mathrm{H} 3 \mathrm{H} 2)=2.96 \mathrm{~Hz}, 1 \mathrm{H}, \mathrm{H} 3\right), 8.22(\mathrm{~s}, 1 \mathrm{H}, \mathrm{H} 4), 11.41(\mathrm{~s}, 1 \mathrm{H}, \mathrm{H} 5), 8.17(\mathrm{t}$, $\left.{ }^{3} J(\mathrm{H} 6 \mathrm{H7})=5.78 \mathrm{~Hz}, 1 \mathrm{H}, \mathrm{H} 6\right), 3.61-3.50(\mathrm{~m}, 2 \mathrm{H}, \mathrm{H7}), 1.11\left(\mathrm{t},{ }^{3} \mathrm{~J}(\mathrm{H} 8 \mathrm{H} 7)=7.08 \mathrm{~Hz}, 3 \mathrm{H}, \mathrm{H} 8\right) . \mathrm{IR} \mathrm{cm}^{-1}$ 3210-3326 ( $\tilde{v} \mathrm{NH}), 1595(\tilde{\mathrm{v}} \mathrm{C}=\mathrm{N}), 810$ ( $\tilde{\mathrm{v}} \mathrm{C}=\mathrm{S}$ ). Anal. Found: $\mathrm{C}, 45.2 ; \mathrm{H}, 5.2 ; \mathrm{N}, 19.6 ; \mathrm{S}, 30.0 \%, \mathrm{C}_{8} \mathrm{H}_{11} \mathrm{~N}_{3} \mathrm{~S}_{2}$ requires $\mathrm{C}, 45.0 ; \mathrm{H}, 5.2 ; \mathrm{N}, 19.7 ; \mathrm{S}, 30.1 \%$.

3.2.3 Compound 3: yield 88\% ${ }^{1} \mathrm{H}$ RMN $\left(D M S O-d_{6}\right) \delta$ ppm $7.69\left(\mathrm{~d},{ }^{3}(\mathrm{H} 1 \mathrm{H} 2)=4.97 \mathrm{~Hz}, 1 \mathrm{H}, \mathrm{H} 1\right), 7.13$ $\left(\mathrm{dd},{ }^{3} \mathrm{~J}(\mathrm{H} 2 \mathrm{H} 1)=4.99,{ }^{3} \mathrm{~J}(\mathrm{H} 2 \mathrm{H} 3)=3.69 \mathrm{~Hz}, 1 \mathrm{H}, \mathrm{H} 2\right), 7.54(\mathrm{~m}, 3 \mathrm{H}, 2 \mathrm{xHo}, \mathrm{H} 3), 9.80(\mathrm{~s}, 1 \mathrm{H}, \mathrm{H} 4), 11.82(\mathrm{~s}$, 


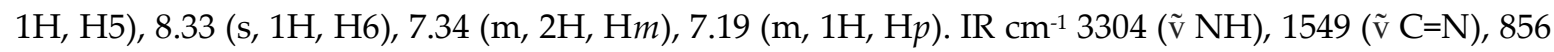
( $\tilde{v} \mathrm{C}=S$ ). Anal. Found: C, 54.6; H, 4.7; N, 16.0; S, $24.0 \%, \mathrm{C}_{12} \mathrm{H}_{11} \mathrm{~N}_{3} \mathrm{~S}_{2}$ requires $\mathrm{C}, 55.1 ; \mathrm{H}, 4.2 ; \mathrm{N}, 16.1 ; \mathrm{S}$, $24.5 \%$.

3.3 Synthesis of the palladium derivatives: an amount of $\mathrm{K}_{2} \mathrm{PdCl}_{4}$ was dissolved in $3 \mathrm{~mL}$ of water, to this $20 \mathrm{~mL}$ of $\mathrm{EtOH}(96 \% \mathrm{v} . \mathrm{v})$ were added to form a suspension and then the corresponding amount of ligand. In the case of compounds $\mathbf{1 a}, \mathbf{2} \mathbf{a}$ and $\mathbf{3 a}$ the stoichiometry ligand: Palladium is 1:1, while in the case of compound $\mathbf{2} \mathbf{b}$ the stoichiometry is $2: 1$. The mixtures were stirred for $24 \mathrm{~h}$ and the yellow precipitates were filtered of, washed with $\mathrm{EtOH}(96 \% \mathrm{v.v})$ and dried.

3.3.1 Compound 1a: yield 83\% ${ }^{1} \mathrm{H}$ RMN (DMSO-d6) $\delta$ ppm $7.66\left(\mathrm{~d}^{3} J(\mathrm{H} 1 \mathrm{H} 2)=5.06 \mathrm{~Hz}, 1 \mathrm{H}, \mathrm{H} 1\right)$, 7.13-7.05 (m, 1H, H2), $7.30(\mathrm{~d}, 3 \mathrm{~J}(\mathrm{H} 3 \mathrm{H} 2)=3.49 \mathrm{~Hz}, 1 \mathrm{H}, \mathrm{H} 3), 8.53$ (s, 1H, H4), 7.82-7.74 (m, 1H, H5),

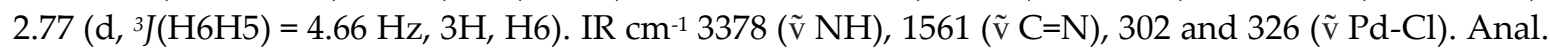
Found: C, 24.6; H, 2.4; N, 12.5; S, $18.9 \%, \mathrm{C}_{14} \mathrm{H}_{16} \mathrm{~N}_{6} \mathrm{~S}_{4} \mathrm{Pd}_{2} \mathrm{Cl}_{2}$ requires $\mathrm{C}, 24.7 ; \mathrm{H}, 2.4 ; \mathrm{N}, 12.4 ; \mathrm{S}, 18.8 \%$. 3.3.2 Compound $2 a$ : yield 88\%, ${ }^{1} \mathrm{H}$ RMN (DMSO-d6) $\delta$ ppm $7.99\left(\mathrm{~d},{ }^{3} J(\mathrm{H} 1 \mathrm{H} 2)=4.98 \mathrm{~Hz}, 1 \mathrm{H}, \mathrm{H} 1\right), 7.21$ $(\mathrm{m}, 1 \mathrm{H}, \mathrm{H} 2), 7.75\left(\mathrm{~d},{ }^{3} \mathrm{~J}(\mathrm{H} 3 \mathrm{H} 2)=3.77 \mathrm{~Hz}, 1 \mathrm{H}, \mathrm{H} 3\right), 8.51(\mathrm{~s}, 1 \mathrm{H}, \mathrm{H} 4), 7.83$ (t, $\left.35(\mathrm{H} 5 \mathrm{H} 6)=5.16 \mathrm{~Hz}, 1 \mathrm{H}, \mathrm{H} 5\right)$,

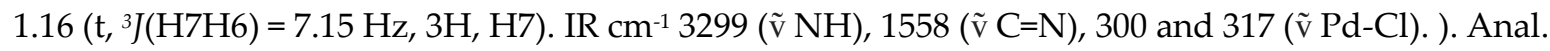
Found: $\mathrm{C}, 27.1 ; \mathrm{H}, 2.8 ; \mathrm{N}, 11.9 ; \mathrm{S}, 18.1 \%, \mathrm{C}_{16} \mathrm{H}_{20} \mathrm{~N}_{6} \mathrm{~S}_{4} \mathrm{Pd}_{2} \mathrm{Cl}_{2}$ requires $\mathrm{C}, 27.1 ; \mathrm{H}, 2.9 ; \mathrm{N}, 11.8 ; \mathrm{S}, 18.1 \%$. 3.3.3 Compound $2 \boldsymbol{b}$ : yield 70\% ${ }^{1} \mathrm{H}$ RMN $\left(D M S O-d_{6}\right) \delta$ ppm $7.93\left(\mathrm{~d},{ }^{3}(\mathrm{H} 1 \mathrm{H} 2)=5.12 \mathrm{~Hz}, 1 \mathrm{H}, \mathrm{H} 1\right)$, 7.20-7.15 (m, 1H, H2), $7.63\left(\mathrm{~d},{ }^{3} \mathrm{~J}(\mathrm{H} 3 \mathrm{H} 2)=3.37 \mathrm{~Hz}, 1 \mathrm{H}, \mathrm{H} 3\right), 7.68(\mathrm{~s}, 1 \mathrm{H}, \mathrm{H} 4), 8.07-8.02(\mathrm{~m}, 1 \mathrm{H}, \mathrm{H} 5)$, $1.17\left(\mathrm{dt},{ }^{3} \mathrm{~J}(\mathrm{H} 6 \mathrm{H} 5),=7.12,{ }^{3} \mathrm{~J}(\mathrm{H} 6 \mathrm{H} 7)=3.23 \mathrm{~Hz}, 2 \mathrm{H}, \mathrm{H} 6\right) . \mathrm{IR} \mathrm{cm}^{-1} 3382(\tilde{\mathrm{v}} \mathrm{NH}), 1517$ (ĩ C=N). ). Anal. Found: $\mathrm{C}, 35.8 ; \mathrm{H}, 4.3 ; \mathrm{N}, 15.4 ; \mathrm{S}, 23.7 \%, \mathrm{C}_{16} \mathrm{H}_{20} \mathrm{~N}_{6} \mathrm{~S}_{4} \mathrm{Pd} 2$ requires $\mathrm{C}, 36.2 ; \mathrm{H}, 3.8 ; \mathrm{N}, 15.4 ; \mathrm{S}, 24.2 \%$. 3.3.4 Compound 3a: yield 96\% ${ }^{1} \mathrm{H}$ RMN (DMSO-d6) $\delta$ ppm $8.00(\mathrm{~d}, 3 \mathrm{~J}=4.9 \mathrm{~Hz}, 1 \mathrm{H}, \mathrm{H} 1), 7.78(\mathrm{~d}, 3 \mathrm{~J}=4.9$ Hz, 1H, H3) 9.84 (s, 1h, H4), 8.13 (s, 1H, H5), 7.68-7.03 (m 6H, H2, Ho, Hm, Hp). IR cm-1 3370 (ĩ NH),

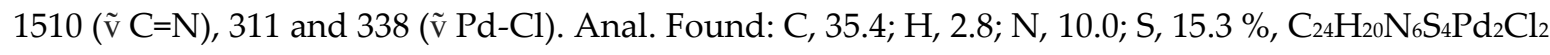
requires $\mathrm{C}, 35.8 .1 ; \mathrm{H}, 2.5 ; \mathrm{N}, 10.5 ; \mathrm{S}, 15.9 \%$.

Table 2: crystallographic data for compound $2 b$

\begin{tabular}{|c|c|}
\hline Empirical formula & $\mathrm{C}_{32} \mathrm{H}_{40} \mathrm{~N}_{12} \mathrm{Pd}_{2} \mathrm{~S}_{8}$ \\
\hline Molecular weight & 1006.07 \\
\hline Temperature & 293(2) K \\
\hline Wavelength & $0,71073 \AA$ \\
\hline Crystal system & Triclínico \\
\hline \multirow[t]{2}{*}{ Space group } & $\mathrm{P}-1$ \\
\hline & $a=10.779(5) \AA, \alpha=89.769(5)^{\circ}$ \\
\hline Unit cell dimensions & $b=15.898(5) \AA, \beta=82.885(5)^{\circ}$ \\
\hline & $c=16.653(5) \AA, \gamma=87.574(5)^{\circ}$ \\
\hline Volume & 2829.2(18) А̊ \\
\hline Z & 2 \\
\hline Calculated density & $1.366 \mathrm{mg} / \mathrm{m} 3$ \\
\hline Absorption coefficient & $1.045 \mathrm{~mm}-1$ \\
\hline $\mathrm{F}(000)$ & 1170 \\
\hline Crystal size & $0,04 \times 0,06 \times 0,08 \mathrm{~mm} 3$ \\
\hline$\theta$ range for data collection & $1,23-26,48^{\circ}$ \\
\hline Index ranges & $-13 \leq \mathrm{h} \leq 13,-19 \leq \mathrm{k} \leq 19,-19 \leq 1 \leq 20$ \\
\hline Reflections collected/independent & 38992 / $11630[\mathrm{R}(\mathrm{int})=0,1129]$ \\
\hline Data/restraints/parameters & $11630 / 0 / 633$ \\
\hline Goodness-of-fit on $\mathrm{F}^{2}$ & 0,997 \\
\hline Final $R$ indices $[\mathrm{I}>2 \sigma(\mathrm{I})]$ & $\mathrm{R} 1=0,0641, \mathrm{wR} 2=0,1331$ \\
\hline R índices (all data) & $\mathrm{R} 1=0,1387, \mathrm{wR} 2=0,1660$ \\
\hline
\end{tabular}


3.4 Catalysis: the catalysis proves were carried out in a Radley Carousel 12 Plus Reaction Station with $6 \mathrm{~mL}$ of a mixture of solvents THF:water 1:2, using as substrates 4-bromoanisole, 4-bromoacetophenone and phenylboronic acid and $\mathrm{K}_{3} \mathrm{PO}_{4}$ as base.

\section{Conclusions}

This communication shows that thiosemicarbazones act as bidentate ligands and their coordination towards the metal is in the thiol form as shown by ${ }^{1} \mathrm{H}$ NMR, IR and X-ray diffraction. The metalated compounds were tested for the Suzuki-Miyaura reaction as catalyst. The results were that these compounds were not such good catalyst as the cyclopalladated derivatives. However, compound 2a shows good conversion in the most favourable conditions. In addition, these experiments prove that the changes in the NHR part of the ligand considerably affect the catalytic activity of the metalated compound.

Acknowledgments: this work was made possible thanks to the financial support received from the Xunta de Galica (Galicia, Spain) under the Grupos de Referencia Competitiva Programme (Project GRC2015/009). F.L.-M. and F. R. thank the Spanish Ministry of Education (grants FPU13/05014 and FPU15/07145).

Conflicts of Interest: The authors declare no conflict of interest. The founding sponsors had no role in the design of the study; in the collection, analyses, or interpretation of data; in the writing of the manuscript, and in the decision to publish the results.

\section{References}

1. Tsuji, J.; Palladium Reagents and Catalysts: Innovations in Organic Synthesis, Wiley, New York, 1995.

2. Belestkaya, I. P.; Cheprakov, A. V.; Palladacycles in catalysis - a critical survey, J. Organomet. Chem., 2004, 689, 4055 - 4082, 10.1016/j.jorganchem.2004.07.054.

3. Casas, J. S.; García-Tasende, M. S.; Sordo, J.; Main group metal complexes of semicarbazones and thiosemicarbazones. A structural review; Coord. Chem. Rev. 200, 209, 197-261. 10.1016/S0010-8545(00)00363-5.

4. Martínez, J.; Pereira, M. T.; Ortigueira, J. M.; Bermúdez, B.; Antelo, J. M.; Fernández, A.; Vila, J. M.; Synthesis and structural characterization of tridentate $[\mathrm{C}, \mathrm{N}, \mathrm{S}]$ thiosemicarbazone palladacycles. Crystal and molecular structures of $\quad\left[\mathrm{Pd}\left\{3-\mathrm{FC}_{6} \mathrm{H}_{3} \mathrm{C}(\mathrm{Me})=\mathrm{NN}=\mathrm{C}(\mathrm{S}) \mathrm{NHMe}\right\}\right]_{4}$, $\left[\mathrm{Pd}\left\{4-\mathrm{FC}_{6} \mathrm{H}_{3} \mathrm{C}(\mathrm{Me})=\mathrm{NN}=\mathrm{C}(\mathrm{S}) \mathrm{NHEt}\right\}\right]_{4}$ and $\quad\left[\left(\mathrm{Pd}\left\{2-\mathrm{BrC}_{6} \mathrm{H}_{3} \mathrm{C}(\mathrm{Me})=\mathrm{NN}=\mathrm{C}(\mathrm{S}) \mathrm{NHPh}\right\}\right)_{2}\left(\mu-\mathrm{Ph}_{2} \mathrm{P}\left(\mathrm{CH}_{2}\right)_{2} \mathrm{PPh}_{2}\right)\right]$, Polyhedron, 2012, 31, 217-226, 10.1016/j.poly.2011.09.012.

5. Bermúdez Puente, B.; Compuestos Ciclometalados de Paladio y Platino. Reacciones de acoplamiento y catálisis. PhD Dissertation. Santiago de Compostela 2014.

6. Miyaura, N.; Yamada, K.; Suzuki, A.; A New Stereospecific Cross-Coupling by the Palladium-Catalyzed Reaction of 1-Alkenylboranes with 1-Alkenyl or 1-Alkynyl Halides; Tetrahedron Letters, 1979, 20, 3437-3440. doi:10.1016/S0040-4039(01)95429-2.

7. Lucio-Martinez, F.; Adrio, L. A.; Polo-Ces, P.; Ortigueira, J. M.; Fernandez, J. J.; Adams, H.; Pereira, M. T.; Vila, J. M.; Palladacycle catalysis: an innovation to the Suzuki-Miyaura cross-coupling reaction, Dalton Trans. 2016, 45, 17598-17601. 10.1039/C6DT03542F.

8. Willes, D. M.; Suprunchuck, $\mathrm{T}$;; The $\mathrm{C}=\mathrm{S}$ stretching vibration in the infrared spectra of some thiosemicarbazones. II. Aldehyde thiosemicarbazones containing aromatic groups, Can. J. Chem., 1967, 45, 2258

9. Perrin, D.D., Armarego, W.L.F. Purification of Laboratory Chemicals, Butterworth-Heinemann, London, $4^{\text {th }}$ ed., 1996

(C) 2017 by the authors. Submitted for possible open access publication under the terms and conditions of the Creative Commons Attribution (CC BY) license (http://creativecommons.org/licenses/by/4.0/). 